A N N A L E S

UNIVERSITATIS MARIAE CURIE-SKŁODOWSKA

LUBLIN - POLONIA

VOL. LXVI, 2

SECTIO G

2019

Uniwersytet Rzeszowski

\author{
SŁAWOMIR ZWOLAK \\ sla_z@poczta.fm \\ ORCID: 0000-0002-4075-4400
}

\title{
Glosa do uchwały Naczelnego Sądu Administracyjnego z dnia 3 listopada 2016 r. (II OPS 1/16, LEX nr 2116795)
}

Gloss to the Resolution of the Supreme Administrative Court of 3 November 2016 (II OPS 1/16, LEX No. 2116795)

Do robót budowlanych i obiektów budowlanych, które nie wymagają uzyskania pozwolenia na budowę i nie są objęte obowiązkiem zgłoszenia, mogą być stosowane przepisy art. 50 ust. 1 pkt 2 lub pkt 4 in fine ustawy z dnia 7 lipca 1994 r. Prawo budowlane ${ }^{1}$, a także art. 51 ust. 7 tej ustawy, jeżeli roboty budowlane zostały wykonane w sposób, o którym mowa w art. 50 ust. 1 pkt 2 lub pkt 4 in fine.

W przedmiotowej uchwale Naczelny Sąd Administracyjny odniósł się do wniosku Rzecznika Praw Obywatelskich w sprawie pytania, czy przepisy art. 50 ust. 1 pkt 2, art. 50 ust. 1 pkt 4 in fine oraz art. 51 ust. 7 w zw. $\mathrm{z}$ art. 50 ust. 1 pkt 2 i w zw. z art. 50 ust. 1 pkt 4 in fine ustawy z dnia 7 lipca 1994 r. - Prawo budowlane znajdują zastosowanie w stosunku do robót budowlanych i obiektów budowlanych, których realizacja ani nie wymaga uzyskania pozwolenia na budowę, ani nie jest objęta obowiązkiem zgłoszenia.

Dotychczas w tej sprawie obowiązywały dwie odmienne linie orzecznicze. Według pierwszej z nich wstrzymanie robót budowlanych prowadzonych w sposób mogący spowodować zagrożenie bezpieczeństwa ludzi lub mienia bądź zagrożenie środowiska lub w sposób istotnie odbiegający od ustaleń i warunków

$1 \quad$ T.j. Dz.U. 2018, poz. 1202 z późn. zm., dalej jako: pr. bud. 
określonych w przepisach możliwe było tylko w przypadku robót budowlanych, co do których istniał obowiązek uzyskania pozwolenia na budowę albo dokonania zgłoszenia. W przypadku rozpoczętych robót budowlanych, na których nie wymaga się pozwolenia na budowę albo zgłoszenia, takie roboty nie będą mieć cech samowoli budowlanej, które z kolei prowadzą do likwidacji przez uprawnione organy nadzoru budowlanego. Rezultat tych robót budowlanych, o ile powoduje negatywne uciążliwości dla osób trzecich i ich nieruchomości, kwalifikuje się jako szkoda w rozumieniu przepisów kodeksu cywilnego, do naprawienia której właściwa jest droga przed sądami powszechnymi². Natomiast druga linia orzecznicza opowiadała się za dopuszczalnością stosowania wymienionych wyżej przepisów do robót budowlanych i obiektów budowlanych, których realizacja nie jest objęta reglamentacją prawnobudowlaną̧3.

Skład orzekający w glosowanej uchwale przede wszystkim wziął pod uwagę treść art. 1 pr. bud., który stanowi, że ustawa ta normuje działalność obejmującą sprawy projektowania, budowy, utrzymania i rozbiórki obiektów budowlanych oraz określa zasady działania organów administracji publicznej w tych dziedzinach. Jak zauważył Naczelny Sąd Administracyjny, analiza ustawy Prawo budowlane pokazuje, że ustawodawca konsekwentnie na każdym etapie procesu budowlanego przywiązuje zasadniczą wagę do przeciwdziałania powstawaniu zagrożenia bezpieczeństwa ludzi lub mienia bądź zagrożenia środowiska. Istotną regulację w tej kwestii zawiera art. 81 ust. 1 pkt 1 lit. b pr. bud., w myśl którego do podstawowych obowiązków organów administracji architektoniczno-budowlanej i nadzoru budowlanego należy nadzór i kontrola nad przestrzeganiem przepisów prawa budowlanego, a w szczególności nad przestrzeganiem warunków bezpieczeństwa ludzi i mienia w rozwiązaniach przyjętych w projektach budowlanych przy wykonywaniu robót budowlanych oraz utrzymywaniu obiektów budowlanych. Obowiązek organów do zapewnienia nadzoru i kontroli warunków bezpieczeństwa ludzi i mienia obejmuje zatem rozwiązania przyjęte $\mathrm{w}$ projektach budowlanych, które są zatwierdzane w decyzji o pozwoleniu na budowę, a także przy wykonywaniu jakichkolwiek robót budowlanych oraz utrzymywaniu wszystkich obiektów budowlanych, niezależnie od tego, czy te roboty lub obiekty budowlane podlegają obowiązkowi uzyskania pozwolenia na budowę albo zgłoszenia.

2 Zob. wyrok NSA z dnia 4 listopada 2014 r., II OSK 7/14, LEX nr 1658623; wyrok NSA z dnia 2 października 1998 r., IV SA 1758/96, LEX nr 43782; wyrok WSA we Wrocławiu z dnia 30 marca 2006 r., II SA/Wr 564/04, LEX nr 825451; wyrok WSA w Krakowie z dnia 15 maja 2014 r., II SA/Kr 308/14, LEX nr 1531395.

3 Zob. postanowienie NSA z dnia 23 lutego 2010 r., II OW 27/09, LEX nr 566005; wyrok NSA z dnia 20 maja 2011 r., II OSK 911/10, LEX nr 992664; wyrok WSA w Szczecinie z dnia 9 lutego 2014 r., II SA/Sz 1135/05, LEX nr 873077; wyrok WSA w Gliwicach z dnia 19 czerwca 2015 r., II SA/GL 1501/14, LEX nr 1790084. 
Wyjaśniając przepisy prawne, których stosowanie wywołało rozbieżności w orzecznictwie sądów administracyjnych, Naczelny Sąd Administracyjny zauważył, że dokonując wykładni art. 50 ust. 1 pkt 2 pr. bud., nie można poprzestać na wykładni gramatycznej, gdyż nie daje ona jednoznacznych wyników. Zakres przedmiotowy tego przepisu został określony przez odesłanie do przypadków innych niż określone $\mathrm{w}$ art. 48 ust. 1 lub art. $49 \mathrm{~b}$ ust. 1 pr. bud. W przepisach tych jest z kolei mowa o obiektach budowlanych będących w budowie albo wybudowanych bez wymaganego pozwolenia na budowę albo bez wymaganego zgłoszenia bądź pomimo wniesienia sprzeciwu przez właściwy organ. Nie sposób zatem jednoznacznie stwierdzić, czy ustawodawca miał na myśli jedynie przypadki prowadzenia innych robót budowlanych, o których mowa w art. 3 pkt 7 pr. bud., innych niż budowa w rozumieniu art. 3 pkt 6 pr. bud., bez wymaganego pozwolenia na budowę albo bez wymaganego zgłoszenia bądź pomimo wniesienia sprzeciwu przez właściwy organ, czy również przypadki prowadzenia tego rodzaju robót, nawet jeżeli nie podlegają one takiej reglamentacji. Decydujące znaczenie w takiej sytuacji ma wykładnia systemowa oraz celowościowa wymienionych przepisów. Ponadto, jak zauważył Naczelny Sąd Administracyjny, w powyższym zakresie oceny prawnej należy przede wszystkim przywołać art. 5 ust. 1 pr. bud., zgodnie z którym każdy obiekt budowlany jako całość oraz jego poszczególne części, wraz ze związanymi z nim urządzeniami budowlanymi, należy, biorąc pod uwagę przewidywany okres użytkowania, projektować i budować w sposób określony $\mathrm{w}$ przepisach, w tym techniczno-budowlanych, oraz zgodnie z zasadami wiedzy technicznej, zapewniając spełnienie podstawowych wymagań dotyczących obiektów budowlanych.

W ocenie składu orzekającego regulacje prawa budowlanego jednoznacznie gwarantują organom administracji architektoniczno-budowlanej i organom nadzoru budowlanego możliwość ingerencji w sytuacjach zagrożenia bezpieczeństwa ludzi lub mienia bądź zagrożenia środowiska na każdym etapie realizacji i utrzymania obiektu budowlanego. Naczelny Sąd Administracyjny doszedł do wniosku, że przyjęcie założenia, że organy te nie mogą sprawować nadzoru budowlanego wobec realizowanych obiektów i robót budowlanych niewymagających pozwolenia na budowę albo zgłoszenia, jeżeli stwierdzą wystąpienie zagrożenia bezpieczeństwa ludzi lub mienia bądź zagrożenia środowiska, byłoby niespójne z tymi regulacjami, nieracjonalne i sprzeczne $\mathrm{z}$ interesem publicznym, który stanowi istotę celowości działania organów budowlanych. Według Naczelnego Sądu Administracyjnego orzeczenia sądów administracyjnych wskazują, że problem zakresu przedmiotowego art. 50 i 51 pr. bud. w większości przypadków pojawia się przy realizacji ogrodzeń. Przyjęcie zatem poglądu, że art. 50 pr. bud. nie odnosi się do obiektów i robót budowlanych niewymagających pozwolenia na budowę albo zgłoszenia, oznaczałoby, że w stosunku do większości ogrodzeń, które nie podlegają obowiązkowi zgłoszenia, organy nadzoru budowlanego nie miałyby 
możliwości wyegzekwowania np. obowiązku wykonywania ogrodzeń w sposób niestwarzający zagrożenia dla bezpieczeństwa ludzi lub zwierząt oraz zakazu umieszczania na wysokości mniejszej niż 1,8 m ostro zakończonych elementów, drutu kolczastego, thuczonego szkła oraz innych podobnych wyrobów i materiałów. Nie do zaakceptowania byłby również brak możliwości wstrzymania przez organ nadzoru budowlanego robót budowlanych wykonywanych w sposób mogący spowodować zagrożenie bezpieczeństwa ludzi lub mienia bądź zagrożenie środowiska tylko dlatego, że nie podlegają one obowiązkowi uzyskania pozwolenia na budowę lub dokonania zgłoszenia.

Naczelny Sąd Administracyjny zwrócił uwagę, że wstrzymanie wykonania robót budowlanych dotyczy także robót budowlanych prowadzonych w sposób istotnie odbiegający od ustaleń i warunków określonych w przepisach (przede wszystkim przepisach techniczno-budowlanych oraz przepisach miejscowych planów zagospodarowania przestrzennego), a nie tylko w sposób niezgodny z wydanym pozwoleniem na budowę albo zgłoszeniem. W związku z tym nie wydaje się możliwy do obrony pogląd, że racjonalny ustawodawca nie zapewniłby procedury umożliwiającej właściwym organom ocenę zgodności realizowanych robót budowlanych z właściwymi przepisami.

W niniejszej glosie zostanie przeprowadzona analiza przedmiotowej uchwały w sprawie robót budowlanych i obiektów budowlanych, które nie wymagają uzyskania pozwolenia na budowę i nie są objęte obowiązkiem zgłoszenia, a podlegają nadzorowi ze strony właściwych organów administracyjnych. Odnosząc się do rozstrzygnięcia przyjętego w uchwale Naczelnego Sądu Administracyjnego, należy najpierw ustalić kwestię nadzoru w procesie budowlanym.

Pojęcie nadzoru w administracyjnym prawie materialnym przysługuje z reguły na oznaczenie funkcji typu policyjnego, mając tu na uwadze nadzór budowlany. Jest to jeden z rodzajów administracji publicznej, skierowany z reguły do obywatela lub innych podmiotów organizacyjnie niezależnych od organów administracji ${ }^{4}$. Chodzi tu o spełnianie funkcji typu policyjnego, które mają na celu: zapobieganie niebezpieczeństwom dla życia i zdrowia jednostki, ochronę środowiska, przestrzeganie reżimów technicznych, wartości ekonomicznych i estetycznych $\mathrm{w}$ trakcie procesów budowlanych oraz w zakresie utrzymywania istniejących obiektów budowlanych ${ }^{5}$. Nadzorem budowlanym można zatem nazwać ogół czynności formalno-prawnych organów administracji budowlanej, których celem jest zapobieganie wszelkim niebezpieczeństwom dla życia, zdrowia i mienia obywatela oraz dla porządku publicznego, a które mogą zagrażać w związku z wykonywaniem robót budowlanych lub niewłaściwym utrzymywaniem budyn-

4 Z. Leoński, Zarys prawa administracyjnego, Warszawa 2004, s. 200.

Z. Leoński, M. Szewczyk, Podstawowe instytucje planowania przestrzennego i prawa budowlanego, Poznań 1997, s. 136. 
ków. W szczególności zadaniem nadzoru budowlanego jest czuwać nad tym, aby przepisy budowlane i zasady sztuki budowlanej były przestrzegane ${ }^{6}$.

Ponadto w świetle przyjętej uchwały należy zauważyć, że ogólna charakterystyka ustawy Prawo budowlane pokazuje, iż jest to akt prawny, który chroni dobra i stany nazwane wartościami. Pobieżny przegląd przepisów prawnych wskazuje, że prawodawca wiąże stosowanie ustawy z określonymi wartościami ${ }^{7}$. Prawo, chroniąc pewne wartości, które z perspektywy społeczeństwa uważa się za konieczne, zakreśla więc jednocześnie granice ingerencji w swobodę działań inwestora poprzez normy prawne ${ }^{8}$. Przede wszystkim potwierdza to zawarta w art. 4 pr. bud. zasada wolności budowlanej jako naczelna zasada prawa budowlanego, która nierzadko doznaje ograniczeń ze względu na wartości chronione. Ograniczenie wolności budowlanej może przede wszystkim wynikać z działań o charakterze policyjnym ujętych w normach prawa budowlanego jako nakazy i zakazy. Działania te kładą nacisk na zakres przedmiotowy ingerencji właściwych organów, które odnoszą się do konkretnego zachowania podmiotów, dotyczących faktycznych działań lub zaniechań i ich rezultatów, które mają odzwierciedlenie w poprawności wykonania określonych obiektów budowlanych ${ }^{9}$. Ograniczenia te są wyrazem potrzeb społecznych zmierzających do zapewnienia bezpieczeństwa, ochrony zdrowia i mienia jednostek ${ }^{10}$. Granice wolności budowlanej, chociaż wyznaczone na drodze ustawowej, określone są już w Konstytucji RP. Zgodnie $\mathrm{z}$ art. 31 ust. 3 Konstytucji $\mathrm{RP}^{11}$ ograniczenia w zakresie korzystania z konstytucyjnych wolności i praw mogą być ustanawiane tylko w ustawie i tylko wtedy,

6 W. Brzeziński, J. Starościak, Administracja budownictwa, [w:] Polskie prawo administracyjne. Część szczegółowa, red. M. Jaroszyński, Warszawa 1957, s. 34; A Filipowicz, Pojęcie i funkcje nadzoru w administracji, Wrocław 1984, s. 56-57.

7 Jak zauważył Sławomir Serafin (Funkcje prawa budowlanego, „Społeczeństwo i Rodzina” 2006, nr 1, s. 88), jedną z podstawowych funkcji prawa budowlanego jest funkcja ochronna, choć nie da się tej funkcji jednoznacznie określić na poziomie teoretycznym, ponieważ w literaturze przedmiotu zagadnienie funkcji prawa budowlanego, a zwłaszcza jego typologia, ujęte jest w sposób ogólny i mało precyzyjny.

8 Ochrona dóbr szczególnie cennych dla społeczeństwa stanowi jedną z właściwości przypisywanych policji administracyjnej. Dobra te rozumiane są jako wszystko, co dla ludzi ma określoną wartość, co zaspokaja ich potrzeby, co ludzie cenią i chcą posiadać. Mogą one występować w ujęciu indywidualnym i publicznym, materialnym i niematerialnym. Najczęściej ochrona jednego z nich wiąże się z ochroną innego bądź innych dóbr. Zob. K. Mazur, Dobra chronione w działalności policji administracyjnej na przykladzie państwowej inspekcji sanitarnej, „Przegląd Prawa Publicznego” 2010, nr 3, s. 54.

9 Zob. K. Zamyślewska-Gorząch, Wolność budowlana i jej prawne ograniczenia, „Samorząd Terytorialny" 2005, nr 10, s. 60-61.

10 Zob. M. Wyrzykowski, Legislacja - demokratyczne państwo prawa - radykalne reformy polityczne i gospodarcze, [w:] Tworzenie prawa $w$ demokratycznym państwie prawnym, red. $\mathrm{H}$. Suchocka, Warszawa 1992, s. 45.

11 Konstytucja Rzeczypospolitej Polskiej z dnia 2 kwietnia 1997 r. (Dz.U. nr 78, poz. 483 ze sprost. i późn. zm.). 
gdy są konieczne w demokratycznym państwie dla jego bezpieczeństwa lub porządku publicznego bądź ochrony środowiska, zdrowia i praw innych osób i nie mogą naruszać istoty wolności i praw.

W tym kontekście należy zauważyć, że ingerencja w celu ochrony wartości jest przedmiotem policji administracyjnej. Określenie policji administracyjnej jako sfery ingerencji administracji oznacza, że sfera ta obejmuje swym działaniem ochronę bezpieczeństwa, porządku spokoju publicznego, a zwłaszcza życia, zdrowia i mienia. Rolą policji jest więc zagwarantowanie nienaruszalności dotychczasowego porządku, mienia i niektórych, poddanych ochronie administracyjnoprawnej, dóbr osobistych człowieka ${ }^{12}$, a także kontrola przestrzegania normatywów policyjnych oraz sankcjonowanie obowiązków z nich wynikających ${ }^{13}$. W obszarze prawa budowlanego policja jest określona przez strukturę organów wykonujących działania związane z utrzymaniem bezpieczeństwa i porządku publicznego, ochroną zdrowia i życia ludzkiego ${ }^{14}$. Kompetencje w tym zakresie mają przede wszystkim organy nadzoru budowlanego, czasem określane pojęciem policji budowlanej jako wyspecjalizowanej służby z zakresu regulacji budowlanych ${ }^{15}$.

Funkcja policji budowlanej jest nastawiona na urzeczywistnianie dobra publicznego, przeciwdziałając zjawiskom niebezpiecznym, które mając charakter publiczny, wpływałaby ujemnie na warunki życia zbiorowego ${ }^{16}$. Istotne kompetencje policji budowlanej dotyczą nadzoru budowlanego oddziałującego na procesy budowy i utrzymania obiektów budowlanych, przejawiające się w decyzjach dotyczących zapobiegania powstawaniu niebezpieczeństwa dla życia, zdrowia i mienia, a także porządku publicznego ${ }^{17}$. Policyjny charakter prawa budowlanego pozwala zauważyć, że podstawowym kierunkiem działania policji budowlanej jest utrzymywanie ładu architektoniczno-przestrzennego oraz zapewnienie bezpieczeństwa i porządku prawnego w budownictwie. Jak wcześniej wspomniano, cel ten jest realizowany głównie przy pomocy organów nadzoru budowlanego. Przepisy prawa budowlanego dotyczące nadzoru budowlanego zawierają z reguły nakazy i zakazy typu policyjnego, podyktowane interesem ogólnym, a zwłaszcza wprowadzeniem ładu, porządku i bezpieczeństwa ${ }^{18}$.

12 Zob. J. Boć, [w:] Prawo administracyjne, red. J. Boć, Wrocław 2004, s. 362-363.

13 J. Dobkowski, Policja administracyjna. Zagadnienia doktrynalno-instytucjonalne, ,Samorząd Terytorialny" 2004, nr 7-8, s. 17-18.

14 A. Chajbowicz, O podmiotowym znaczeniu pojęcia policja administracyjna, [w:] Nowe problemy badawcze w teorii prawa administracyjnego, red. J. Boć, A. Chajbowicz, Wrocław 2009, s. 163.

15 Jak wskazuje Zbigniew Leoński (op. cit., s. 466), policję administracyjną mogą spełniać organy „cywilne”, do których w szczególności można zaliczyć różnego rodzaju inspekcje i nadzory (w tym organy nadzoru budowlanego).

16 M. Janik, Policja sanitarna, Warszawa 2012, s. 58.

17 Zob. E. Kulesza, J. Słoniński, Prawo budowlane, Warszawa-Poznań 1978, s. 8-9.

18 Zob. K. Małysa-Sulińska, Administracyjnoprawne aspekty inwestycji budowlanych, Warszawa 2012, s. 26. 
W szczególności bezpieczeństwo jest wartością mocno podkreślaną w przepisach prawa budowlanego. Bezpieczeństwo nie jest abstrakcyjnym pojęciem nauki prawa administracyjnego, gdyż prawo określa niektóre desygnaty tego pojęcia. Bezpieczeństwo jest podstawowym zadaniem władzy publicznej, ściśle związanym z jego funkcją. Przez bezpieczeństwo publiczne należy rozumieć stan, w którym ogółowi obywateli indywidualnie nieoznaczonemu, żyjącemu w państwie i społeczeństwie, nie grozi żadne niebezpieczeństwo i to niezależnie od tego, jakie byłoby jego źródło ${ }^{19}$. Zatem pojęcie bezpieczeństwa można zdefiniować jako pozytywny stan, który zawsze pośrednio lub bezpośrednio dotyczy człowieka, a jego charakterystycznymi elementami są poczucie pewności i brak zagrożenia $^{20}$. Bezpieczeństwo jako jedno z dóbr podlegających ochronie prawnej nie zostało jednak zdefiniowane w żadnym krajowym akcie prawnym. Jedynie w doktrynie oraz literaturze przedmiotu pojęcie to bywa różnie określane i przypisuje mu się różną pojemność semantyczną ${ }^{21}$. Najważniejszym aktem prawnym, który reguluje kwestie dotyczące bezpieczeństwa, jest Konstytucja RP. Zgodnie z art. 5 Konstytucji RP Rzeczpospolita Polska strzeże niepodległości i nienaruszalności swojego terytorium, zapewnia wolności i prawa człowieka i obywatela oraz bezpieczeństwo obywateli, strzeże dziedzictwa narodowego oraz zapewnia ochronę środowiska, kierując się zasadą zrównoważonego rozwoju. Ochrona bezpieczeństwa jest jednym $z$ celów państwa, polegającym na odwracaniu niebezpieczeństw zagrażających państwu, zorganizowanym grupom społecznym i poszczególnym jednostkom ${ }^{22}$. Zapewnienie bezpieczeństwa jest bowiem uznawane za wartość nadrzędną i w związku z tym odpowiednie podmioty są zobowiązane do podejmowania wszelkich działań, aby je zapewniće ${ }^{23}$. Dla skutecznej ochrony bezpieczeństwa ustawodawca wprowadził w art. 5 ust. 1 pr. bud. wymagania podstawowe, które muszą być spełnione na etapie projektowania i budowania. Wymagania te dotyczą dających się przewidzieć oddziaływań w zakresie nośności i stateczności konstrukcji obiektu budowlanego, bezpieczeństwa pożarowego, bezpieczeństwa użytkowania, ochrony środowiska, ochrony przed hałasem i drganiami, odpowiednich warunków higienicznych i zdrowotnych, warunków bezpieczeństwa i higieny pracy oraz warunków bezpieczeństwa i ochrony zdrowia osób przebywających na terenie obiektu budowlanego. Powyższe wymagania, obejmujące wszystkie obiekty, powinny gwarantować realizację celów, które

19 E. Ura, Pojęcie ochrony bezpieczeństwa i porządku publicznego, „Państwo i Prawo” 1974, z. 2 , s. 80 .

20 S. Pieprzny, Administracja bezpieczeństwa i porzadku publicznego, Rzeszów 2008, s. 11.

21 H. Zięba-Załucka, Konstytucyjne aspekty bezpieczeństwa, „Studia Iuridica Lublinensia” 2014, t. 22, DOI: http://dx.doi.org/10.17951/sil.2014.22.0.411, s. 417.

22 D. Gatner, Policja administracyjna (studium z teorii myśli administracyjnej), „Organizacja - Metody - Technika" 1988, nr 8-9, s. 28.

23 Wyrok WSA w Kielcach z dnia 19 stycznia 2007 r., II SA/Ke 544/06, LEX nr 604142. 
co do zasady koncentrują się na zapewnieniu odpowiedniego poziomu bezpieczeństwa konstrukcyjnego, pożarowego i użytkowego dla ludzi i mienia oraz właściwej ochrony zdrowia i środowiska ${ }^{24}$.

Aby zapewnić spełnienie podstawowych wymagań przy realizacji obiektów budowlanych, ustawodawca w art. 81 ust. 1 pkt 1 pr. bud. nałożył na właściwe organy administracji publicznej obowiązek nadzoru i kontroli nad przestrzeganiem przepisów prawa budowlanego, a w szczególności: 1) zgodności zagospodarowania terenu z miejscowymi planami zagospodarowania przestrzennego oraz wymaganiami ochrony środowiska; 2) warunków bezpieczeństwa ludzi i mienia $\mathrm{w}$ rozwiązaniach przyjętych w projektach budowlanych przy wykonywaniu robót budowlanych i utrzymywaniu obiektów budowlanych; 3) zgodności rozwiązań architektoniczno-budowlanych z przepisami techniczno-budowlanymi oraz zasadami wiedzy technicznej; 4) właściwego wykonywania samodzielnych funkcji w budownictwie; 5) stosowania odpowiednich wyrobów budowlanych. Szczegółowe zadania i kompetencje wskazuje art. 83 ust. 1 pr. bud., według którego do właściwości organu nadzoru budowlanego należą m.in. zadania wynikające z przepisów art. 48-51 pr. bud. Zgodnie z przepisem art. 50 ust. 1 pkt 4 pr. bud. w innych wypadkach niż określone w art. 48 ust. 1 i art. $49 \mathrm{~b}$ ust. 1 pr. bud. (czyli gdy roboty budowlane są prowadzone bez uzyskania koniecznego pozwolenia na budowę lub zgłoszenia) organ nadzoru budowlanego wstrzymuje prowadzenie robót budowlanych w sposób istotnie odbiegający od ustaleń i warunków określonych w pozwoleniu na budowę bądź w przepisach. Następstwem tego może być nałożenie obowiązku rozbiórki tego obiektu lub jego części. Zgodnie zaś z przepisem art. 51 ust. 7 pr. bud. przepisy art. 51 ust. 1 pkt 1 i 2 oraz ust. 3 pr. bud. stosuje się odpowiednio, jeżeli roboty budowlane, w przypadkach innych niż określone w art. 48 lub 49b pr. bud., zostały wykonane w sposób, o którym mowa w art. 50 ust. 1 pr. bud.

W literaturze podkreśla się, że celem postępowania naprawczego uregulowanego w art. 50 i 51 pr. bud. jest przeciwdziałanie niekorzystnym z punktu widzenia interesu społecznego oraz interesu poszczególnych obywateli naruszeniom reguł prawnych gwarantujących prawidłowy przebieg procesu budowlanego ${ }^{25}$. Dlatego przepisy prawa przewidują dopuszczalność stosowania przepisów prawa budowlanego o wstrzymaniu lub zaniechaniu robót budowlanych, rozbiórce obiektu lub jego części, doprowadzeniu obiektu do stanu poprzedniego i nałożeniu obowiązków w odniesieniu do robót i obiektów budowlanych niewymagających uzyskania pozwolenia na budowę lub jej zgłoszenia, których sposób wykonywania może spowodować zagrożenie bezpieczeństwa ludzi lub mienia bądź zagrożenie środowiska lub w sposób istotnie odbiegający od ustaleń i warunków określonych

24 S. Serafin, Prawo budowlane. Komentarz, Warszawa 2006, s. 131.

25 A. Ostrowska, Pozwolenie na budowe, Warszawa 2012, s. 268. 
w pozwoleniu na budowę, projekcie budowlanym lub w przepisach ${ }^{26}$. Prowadzi to do spostrzeżenia, że roboty i obiekty budowlane, na które prawo nie wymaga uzyskania pozwolenia na budowę lub zgłoszenia, również podlegają regulacjom przewidzianym $\mathrm{w}$ prawie budowlanym, $\mathrm{w}$ tym przepisom techniczno-budowlanym $^{27}$. Roboty budowlane i budowa takiego obiektu podlegają kontroli i ocenie organów nadzoru budowlanego w zakresie zgodności z odpowiednimi regulacjami, zgodnie z kompetencjami organów nadzoru budowlanego wskazanymi w art. 84 pr. bud., a w szczególności art. 84a ust. 1 pkt 1 pr. bud. Organ nadzoru budowlanego, oceniając roboty budowlane, nie może patrzeć wyłącznie z punktu widzenia ich legalności, lecz powinien także mieć na uwadze, czy roboty nie naruszają przepisów. Przedmiotem postępowania naprawczego opartego o art. 50 i $51 \mathrm{pr}$. bud. mogą być bowiem roboty budowlane niepodlegające reglamentacji prawa budowlanego, ale zrealizowane w sposób niezgodny z przepisami. I tak np. W przypadku stwierdzenia nieprawidłowości polegających na naruszeniu przepisów prawa budowlanego, w tym przepisów techniczno-budowlanych (do których należy rozporządzenie Ministra Infrastruktury z dnia 12 kwietnia 2002 r. w sprawie warunków technicznych, jakim powinny odpowiadać budynki i ich usytuowanie ${ }^{28}$ ), organ nadzoru budowlanego zobowiązany jest podjąć działania zmierzające do doprowadzenia do stanu zgodnego z prawem.

W sytuacji przyjęcia odmiennego poglądu przez Naczelny Sąd Administracyjny organy nadzoru budowlanego nie mogłyby ingerować w proces budowlany poprzez określenie konkretnych wymogów techniczno-budowlanych danego obiektu budowlanego, jak również nie byłyby władne do precyzowania takich wymogów w trakcie prowadzenia robót budowlanych lub budowy obiektu, a także po jego wybudowaniu. Gdyby tak było, poza kompetencjami organów nadzoru budowlanego pozostawałaby szeroka działalność inwestycyjna mogąca nie tylko wywoływać zagrożenia, o których mowa w art. 50 ust. 1 pkt 2 pr. bud., ale przede wszystkim naruszać obiektywny porządek, regulowany w tej materii zasadniczo przepisami prawa publicznego. Bez wątpienia taką sytuację należałoby ocenić jako bezprawną, która wymaga w państwie prawa odpowiedniego przeciwdziałania ze strony powołanych do tego organów państwa. Dlatego z prawa budowlanego wynika, że ani przepis art. 1 pr. bud. określający przedmiot regulacji ustawy, ani żaden inny przepis prawa budowlanego nie wyłącza spod działania ustawy określonej kategorii obiektów i robót budowlanych tylko z tego powodu, że ich realizacja nie wymaga uzyskania pozwolenia na budowę lub też nie jest objęta obowiązkiem zgłoszenia.

26 Zob. A. Gliniecki, [w:] Prawo budowlane. Komentarz, red. A. Gliniecki, Warszawa 2016, s. 708 .

27 Zob. E. Radziszewski, Prawo budowlane. Przepisy i komentarz, Warszawa 2005, s. 156;

L. Bar, E. Radziszewski, Nowy kodeks budowlany. Komentarz, Warszawa 1995, s. 91-92.

28 T.j. Dz.U. 2015, poz. 1422. 
Regulacje prawa budowlanego jednoznacznie gwarantują organom nadzoru budowlanego możliwość ingerencji w sytuacjach zagrożenia bezpieczeństwa ludzi lub mienia bądź zagrożenia środowiska na każdym etapie realizacji i utrzymania obiektu budowlanego. Dlatego Naczelny Sąd Administracyjny doszedł do wniosku, że przyjęcie założenia, iż organy te nie mogą sprawować nadzoru budowlanego wobec realizowanych obiektów i robót budowlanych niewymagających pozwolenia na budowę albo zgłoszenia, jeżeli stwierdzą wystąpienie zagrożenia bezpieczeństwa ludzi lub mienia bądź zagrożenia środowiska, byłoby niespójne $\mathrm{z}$ regulacjami prawa budowlanego, nieracjonalne i sprzeczne $\mathrm{z}$ interesem publicznym, który stanowi istotę celowości działania organów nadzoru budowlanego.

Należy w pełni zgodzić się z poglądem Naczelnego Sądu Administracyjnego wyrażonym w komentowanej uchwale. Obiekty i roboty budowlane niewymagające ani pozwolenia, ani zgłoszenia niewątpliwie nie mieszczą się w hipotezie art. 48 pr. bud. Oznacza to konieczność uznania, że mieszczą się w hipotezie art. 50 pr. bud., ponieważ pozostawienie ich bez jakiejkolwiek kontroli organów nadzoru budowlanego, nawet w sytuacji, w której stwarzają zagrożenie i naruszają przepisy, byłoby nie do pogodzenia z zasadami państwa prawa, a w szczególności z policyjnym charakterem regulacji procesu budowlanego. $\mathrm{Z}$ całą pewnością niewystarczające $\mathrm{w}$ tym zakresie byłoby odwołanie się do przepisów prawa cywilnego o naprawieniu szkody, już choćby z tego powo$\mathrm{du}$, że nie byłoby możliwe wówczas przeciwdziałanie szkodzie zanim zostałaby wyrządzona, w czasie gdy roboty budowlane byłyby prowadzone w sposób niebezpieczny.

\section{BIBLIOGRAFIA}

Bar L., Radziszewski E., Nowy kodeks budowlany. Komentarz, Warszawa 1995.

Boć J., [w:] Prawo administracyjne, red. J. Boć, Wrocław 2004.

Brzeziński W., Starościak J., Administracja budownictwa, [w:] Polskie prawo administracyjne. Część szczególowa, red. M. Jaroszyński, Warszawa 1957.

Chajbowicz A., O podmiotowym znaczeniu pojęcia policja administracyjna, [w:] Nowe problemy badawcze w teorii prawa administracyjnego, red. J. Boć, A. Chajbowicz, Wrocław 2009.

Dobkowski J., Policja administracyjna. Zagadnienia doktrynalno-instytucjonalne, „Samorząd Terytorialny" 2004, nr 7-8.

Filipowicz A., Pojęcie i funkcje nadzoru w administracji, Wrocław 1984.

Gatner D., Policja administracyjna (studium z teorii myśli administracyjnej), „Organizacja - Metody - Technika" 1988, nr 8-9.

Gliniecki A., [w:] Prawo budowlane. Komentarz, red. A. Gliniecki, Warszawa 2016.

Janik M., Policja sanitarna, Warszawa 2012.

Konstytucja Rzeczypospolitej Polskiej z dnia 2 kwietnia 1997 r. (Dz.U. nr 78, poz. 483 ze sprost. i późn. zm.).

Kulesza E., Słoniński J., Prawo budowlane, Warszawa-Poznań 1978.

Leoński Z., Zarys prawa administracyjnego, Warszawa 2004. 
Leoński Z., Szewczyk M., Podstawowe instytucje planowania przestrzennego i prawa budowlanego, Poznań 1997.

Małysa-Sulińska K., Administracyjnoprawne aspekty inwestycji budowlanych, Warszawa 2012.

Mazur K., Dobra chronione w działalności policji administracyjnej na przykładzie państwowej inspekcji sanitarnej, „Przegląd Prawa Publicznego” 2010, nr 3.

Ostrowska A., Pozwolenie na budowe, Warszawa 2012.

Pieprzny S., Administracja bezpieczeństwa i porzadku publicznego, Rzeszów 2008.

Postanowienie NSA z dnia 23 lutego 2010 r., II OW 27/09, LEX nr 566005.

Radziszewski E., Prawo budowlane. Przepisy i komentarz, Warszawa 2005.

Rozporządzenie Ministra Infrastruktury z dnia 12 kwietnia 2002 r. w sprawie warunków technicznych, jakim powinny odpowiadać budynki i ich usytuowanie (t.j. Dz.U. 2015, poz. 1422).

Serafin S., Funkcje prawa budowlanego, „Społeczeństwo i Rodzina” 2006, nr 1.

Serafin S., Prawo budowlane. Komentarz, Warszawa 2006.

Ura E., Pojęcie ochrony bezpieczeństwa i porządku publicznego, „Państwo i Prawo” 1974, z. 2.

Ustawa z dnia 7 lipca 1994 r. - Prawo budowlane (t.j. Dz.U. 2018, poz. 1202 z późn. zm.).

Wyrok NSA z dnia 2 października 1998 r., IV SA 1758/96, LEX nr 43782.

Wyrok NSA z dnia 20 maja 2011 r., II OSK 911/10, LEX nr 992664.

Wyrok NSA z dnia 4 listopada 2014 r., II OSK 7/14, LEX nr 1658623.

Wyrok WSA we Wrocławiu z dnia 30 marca 2006 r., II SA/Wr 564/04, LEX nr 825451.

Wyrok WSA w Kielcach z dnia 19 stycznia 2007 r., II SA/Ke 544/06, LEX nr 604142.

Wyrok WSA w Szczecinie z dnia 9 lutego 2014 r., II SA/Sz 1135/05, LEX nr 873077.

Wyrok WSA w Krakowie z dnia 15 maja 2014 r., II SA/Kr 308/14, LEX nr 1531395.

Wyrok WSA w Gliwicach z dnia 19 czerwca 2015 r., II SA/GL 1501/14, LEX nr 1790084.

Wyrzykowski M., Legislacja - demokratyczne państwo prawa - radykalne reformy polityczne i gospodarcze, [w:] Tworzenie prawa $w$ demokratycznym państwie prawnym, red. H. Suchocka, Warszawa 1992.

Zamyślewska-Gorząch K., Wolność budowlana i jej prawne ograniczenia, „Samorząd Terytorialny” 2005, nr 10.

Zięba-Załucka H., Konstytucyjne aspekty bezpieczeństwa, „Studia Iuridica Lublinensia” 2014, t. 22, DOI: http://dx.doi.org/10.17951/sil.2014.22.0.411.

\section{SUMMARY}

Gloss concerns the resolution of the Supreme Administrative Court of 3 November 2016 (II OPS 1/16, LEX No. 2116795) which refers to the application of building regulations, applicable to construction works and buildings objects the implementation of which is not subject to legal regulation. According to the view expressed by the Supreme Administrative Court, the competent organ may order the abandonment of such construction works, order the demolition of a building or part thereof, or order it to its previous state or impose the obligation to perform construction works or works in a given period in order to carry out construction works to comply with the law. works

Keywords: construction supervision; procedure corrective; building objects; construction

\section{STRESZCZENIE}

Glosa dotyczy uchwały Naczelnego Sądu Administracyjnego z dnia 3 listopada 2016 r. (II OPS 1/16, LEX nr 2116795), która odnosi się do stosowania przepisów prawa budowlanego mających zastosowanie do robót budowlanych i obiektów budowlanych, których realizacja nie jest objęta 
prawną reglamentacją. Zgodnie z poglądem wyrażonym przez Naczelny Sąd Administracyjny właściwy organ może nakazać zaniechanie takich robót budowlanych, rozbiórkę obiektu budowlanego lub jego części bądź doprowadzenie go do stanu poprzedniego albo może nałożyć obowiązek wykonania w określonym terminie czynności lub robót budowlanych w celu doprowadzenia wykonywanych robót budowlanych do stanu zgodnego z prawem.

Słowa kluczowe: nadzór budowlany; postępowanie naprawcze; obiekt budowlany; roboty budowlane 